University of Wollongong

Research Online

Faculty of Science, Medicine and Health -

Papers: part A

Faculty of Science, Medicine and Health

$1-1-2017$

\title{
The existence and break-up of the Antarctic land bridge as indicated by both amphi-Pacific distributions and tectonics
}

\author{
Conrad Van Den Ende \\ Naturalis Biodiversity Center \\ Lloyd T. White \\ Royal Holloway University of London, lloydw@uow.edu.au \\ Peter Van Welzen \\ Naturalis Biodiversity Center
}

Follow this and additional works at: https://ro.uow.edu.au/smhpapers

Part of the Medicine and Health Sciences Commons, and the Social and Behavioral Sciences

\section{Commons}

\section{Recommended Citation}

Van Den Ende, Conrad; White, Lloyd T.; and Van Welzen, Peter, "The existence and break-up of the Antarctic land bridge as indicated by both amphi-Pacific distributions and tectonics" (2017). Faculty of Science, Medicine and Health - Papers: part A. 4533.

https://ro.uow.edu.au/smhpapers/4533

Research Online is the open access institutional repository for the University of Wollongong. For further information contact the UOW Library: research-pubs@uow.edu.au 


\title{
The existence and break-up of the Antarctic land bridge as indicated by both amphi-Pacific distributions and tectonics
}

\begin{abstract}
Amphi-Pacific disjunct distributions between South America and Australasia are correlated with the breakup and changing palaeo-climate of Gondwana. For a long period, with a temperate climate, Antarctica formed a land bridge between Australia and South America, allowing species to disperse/ vicariate between both continents. Dated phylogenies in the literature, showing sister-clades with a distribution disjunction between South America and Australia, were used for the correlation. The initiation of the Antarctic Circumpolar Current, and a change to a colder Antarctic climate is associated with the opening of the Drake Passage between South America and Antarctica at c. $30 \mathrm{Ma}$, and the final separation of Australia and Antarctica along the South Tasman Rise at c. $45 \mathrm{Ma}$. The distribution data highlighted the existence of a "southern disjunct distribution" pattern, which may be the result of continental vicariance/dispersal. This is strongly indicative of a connection between Antarctica, South America and Australia; which later provided a dispersal pathway and facilitated vicariance after break up. The taxa that likely dispersed/vicariated via Antarctica included all species with a more (sub)tropical climate preference. Twelve distributions, younger than $30 \mathrm{Ma}$, are interpreted as the result of long distance dispersal between South America and Australia; these taxa are suited to a temperate climate. The climatic signal shown by all taxa is possibly a consequence of the Australian plate's asynchronous rifting over tens of millions of years in combination with climate changes. These events may have provided opportunities for tropical and sub-tropical species to disperse and speciate earlier than what we observe for the more temperate taxa.

\section{Disciplines}

Medicine and Health Sciences | Social and Behavioral Sciences

\section{Publication Details}

Van Den Ende, C., White, L. T. \& Van Welzen, P. C. (2017). The existence and break-up of the Antarctic land bridge as indicated by both amphi-Pacific distributions and tectonics. Gondwana Research, 44 219-227.
\end{abstract}




\title{
The existence and break-up of the Antarctic land bridge as indicated by both amphi- Pacific distributions and tectonics
}

Short title: Antarctic land bridge explained by distributions and tectonics

\section{Conrad van den Ende ${ }^{1}$, Lloyd T. White ${ }^{2}$, and Peter C. van Welzen ${ }^{1,3^{*}}$}

${ }^{1}$ Naturalis Biodiversity Center, 2300 RA Leiden, The Netherlands; ${ }^{2}$ Southeast Asia Research Group, Department of Earth Sciences, Royal Holloway University of London, Egham, Surrey, TW20 0EX, UK, ${ }^{3}$ Institute Biology Leiden, Leiden University, 2300 RA Leiden, The Netherlands.

*Email: peter.vanwelzen@ naturalis.nl.

\begin{abstract}
Amphi-Pacific disjunct distributions between South America and Australasia are correlated with the breakup and changing palaeo-climate of Gondwana. For a long period, with a temperate climate, Antarctica formed a land bridge between Australia and South America, allowing species to disperse/vicariate between both continents. Dated phylogenies in the literature, showing sister-clades with a distribution disjunction between South America and Australia, were used for the correlation. The initiation of the Antarctic Circumpolar Current, and a change to a colder Antarctic climate is associated with the opening of the Drake Passage between South America and Antarctica at c. 30 Ma, and the final separation of Australia and Antarctica along the South Tasman Rise at c. 45 Ma. The distribution data highlighted the existence of a "southern disjunct distribution" pattern, which may be the
\end{abstract}


result of continental vicariance/dispersal. This is strongly indicative of a connection between Antarctica, South America and Australia; which later provided a dispersal pathway and facilitated vicariance after break up. The taxa that likely dispersed/vicariated via Antarctica included all species with a more (sub)tropical climate preference. Twelve distributions, younger than $30 \mathrm{Ma}$, are interpreted as the result of long distance dispersal between South America and Australia; these taxa are suited to a temperate climate. The climatic signal shown by all taxa is possibly a consequence of the Australian plate's asynchronous rifting over tens of millions of years in combination with climate changes. These events may have provided opportunities for tropical and sub-tropical species to disperse and speciate earlier than what we observe for the more temperate taxa.

Key-words: Antarctica; Australia, Disjunct distributions; Dispersal; South America; Vicariance 


\section{Introduction}

\section{Amphi-Pacific distributions}

The Southern Beech (Nothofagus Blume, Nothofagaceae) shows a disjunct distribution, it is present in South America and Australasia, a distribution also known as an "amphi-Pacific distribution". Van Steenis (1962) explicitly rejected the theory of continental drift (Wegener, 1929) to explain such phenomena. He instead explained that the distribution occurred due to dispersal via Pacific land bridges between the northern and southern hemispheres in the Cretaceous (145-66 Ma), and he especially favored an Antarctic land bridge. While the mechanism proposed to explain this initial prediction was incorrect, van Steenis (1962) described multiple plant genera that exhibit similar disjunct distribution patterns that we now describe as "Gondwanan" or "Plant Southern Pattern" (Sanmartín and Ronquist, 2004), for example: Hebe Comm. ex Juss. (Plantaginaceae), Oreomyrrhis Endl. (Apiaceae), Donatia J.R.Forst. \& G.Forst. (Stylidiaceae).

Many more "southern disjunct distributions" (SDDs) are now recognized (Table 1 for those with dated phylogenies). The high number of examples indicates that the disjunction did not always consist of a major barrier, Antarctica seemingly acted as general pathway between South America and Australia.

The aim of our research was to search for a possible correlation between the South American-Antarctic-Australian land bridge and the timing of amphi-Pacific disjunctions from dated phylogenies (as well as to date the phylogeny of the Rhamnaceae - see Supporting information). We demonstrate that Antarctica could fulfill its role as a connection for quite a long period based on the plate's tectonic history, after which we present the supporting biological evidence.

Gondwana, its break-up and the possibility of land bridges 
Gondwana consisted of an amalgamation of what are presently Antarctica, Africa, India, South America and Australia as well as islands like Madagascar, New Zealand and New Caledonia (Gaina et al., 1998, 2007; Boger, 2011; Veevers, 2012; White et al., 2013; Reeves, 2014) (Fig. 1). Rifting between many of these fragments commenced as early as the Carboniferous (359-299 Ma) and continued at different times through to the Late Jurassic (165-145 Ma) (Boger, 2011). The periods of crustal extension resulted in the generation of large rift basins (much like the modern-day East African Rift System), but did not always lead to continental break-up (e.g. the Karoo basins of Africa and the Gondwanan basins of India). However, subsequent phases of crustal extension between the various Gondwanan continents eventually resulted in the generation of new seafloor and the opening of large ocean basins (Gaina et al., 1998, 2007; White et al., 2013; Reeves, 2014, Eagles and Jokat, 2014). This process of rifting and eventual sea-floor spreading was quite protracted and occurred in different locations at different times between the Jurassic and Eocene.

Antarctica can effectively be considered the core of Gondwana as all of the other continents were torn from it. The first oceanic crust to be generated between Australia and Antarctica occurred south of Western Australia at around $96 \mathrm{Ma}$, with rifting progressively propagating eastwards leading to the gradual development of a narrow sea between the two landmasses (White et al., 2013; Sayers et al., 2001; Tikku and Direen, 2008). It was not until c. $45 \mathrm{Ma}$ that Australia and Antarctica finally tore apart south of Tasmania and the South Tasman Rise (White et al., 2013) (Fig. 2) as defined by the oldest confident interpretations of magnetic seafloor anomalies south of the South Tasman Rise (Royer and Rollet, 1997; Lawver and Gahagan, 2003). The South Tasman Rise was submerged at this time, and potentially covered by waters as deep as 1,000 m from 50-32 Ma (Exon et al., 2001; Lawver and Gahagan, 2003) (Fig. 2). There would have been 200-300 km of ocean immediately to the west of Tasmania and the South Tasman Rise, as well as between the South Tasman Rise 
and Wilkes Land by c. $40 \mathrm{Ma}$ (Lawver and Gahagan, 2003) (Fig. 2). However, steady throughflow between Australia and Antarctica did not develop until the two continents were clearly separated and when the South Tasman Rise rapidly subsided in the Late Eocene (35$30 \mathrm{Ma}$ ) (Exon et al, 2001; White et al., 2013; Scher et al., 2015) (Fig. 2).

Rifting between South America and western Antarctica occurred between 50-30 Ma (Eagles and Jokat, 2014). This led to the development of several sedimentary basins and the opening of an intermediate depth oceanic gateway between 50-30 Ma. Deep flow was only possible after the initiation of seafloor spreading and the first generation of oceanic crust at $c$. $30 \mathrm{Ma}$ on the West Scotia Ridge (Eagles and Jokat, 2014) (Fig. 2). Continued sea floor spreading in the Scotia Sea led to the opening of the Drake Passage between 30-20 Ma along with much deeper waters and the Antarctic Circumpolar Current (Lawver and Gahagan, 2003; Eagles and Jokat, 2014) (Fig. 2).

The final separation between South America and Antarctica is thought to coincide with the onset of the Antarctic Circumpolar Current, at 30 Ma-28 Ma (McLoughlin, 2001; Lawver and Gahagan, 2003). The initial Drake Passage would have been an extremely narrow, deep seaway at c. $30 \mathrm{Ma}$ (Eagles and Jokat, 2014). It was also likely that a chain of islands persisted between South America and Antarctica during the opening of the Drake Passage and this may have facilitated biotic dispersal from Antarctica well into the Oligocene (Hill, 2009; Eagles and Jokat, 2014) (Fig. 2). So, the Antarctic land bridge may have at first existed as a terrestrial connection during the Jurassic and Cretaceous, but evolved into islands separated by narrow, shallow water bodies (first lakes, later seas) through the Eocene and perhaps until the Oligocene.

\section{Biological background}


The tectonic breakup of South America, Antarctica and Australia can be simplified and classified into three phases (I, II \& III) that are important for different biological processes. Phase I (before $45 \mathrm{Ma}$ ), is when all three areas were connected (with a gradual separation of Australia and Antarctica occuring from west to east, from 90 Ma onwards); Phase II (between c. $45 \mathrm{Ma}$ and $30 \mathrm{Ma}$ ) defines when Australia and Antarctica separated (with South America still attached to Antarctica), and Phase III ( $<30 \mathrm{Ma})$ is when all three continents were separate.

Three dispersal mechanisms may explain the disjunct amphi-Pacific distributions (1) Vicariance: widespread ancestral species that evolve into daughter species when areas split; (2) Pseudo-vicariance: dispersal and speciation as soon as biota colonize a new region; (3) Long distance dispersal (LDD): dispersal via rafts of vegetation or via the air/wind) (Sanmartín and Ronquist, 2004; Sanmartín et al., 2007; Crisp et al., 2009; Winkworth et al., 2015). The lack of preserved Antarctic fossils meant that we were often unable to distinguish between these mechanisms with absolute certainty. A real absence of fossils is indicative of LDD. The same fossil species existing in pre-split S America-Antarctica-Australia is indicative of vicariance, while different species in the three areas may mean pseudovicariance.

The break-up history of Gondwana provides some guidance to the interpretation of dispersal patterns. However, other factors such as regional changes in climate, driven by (i) the global climate, which is in turn forced by Milankovitch cyclicity, oceanic circulation, volcanism, greenhouses gases, etc. (e.g., Zachos et al., 2001), and (ii) by plate tectonic driven movement through latitudinal zones (Supplementary Video in Supporting Information).

Based on the successive climates of Gondwana, illustrated in Fig. 3 by the temperature curve after Zachos et al. (2001), we believe that tropical Gondwanan genera may exhibit earlier disjunctions than temperate genera as the latitudinal drift of Australia and South 
America resulted in their northern regions reaching warmer climatic belts (Supplementary Video). These climatic belts act as barriers to dispersal and establishment for many species. Additionally, high southern latitudes may experience relatively warm, or even sub-tropical climates during hot house episodes, and the northward movement of the plates through different latitudinal zones would also mean biota would experience a shift in sunlight periods during winter months. These would therefore act as additional barriers to dispersal, particularly for many plant species and, indirectly, taxa depending on the plants.

\section{Materials and Methods}

A database of amphi-Pacific (South American vs. Australasian) genera was compiled from the plant specimen database of Naturalis Biodiversity Center. We selected all families with appearances in the Americas and Australia-Asia, but absent in Africa. A web search was performed on the resulting genera and families for dated phylogenies. We then also searched published literature for additional examples as well as for corresponding molecular phylogenies for each taxon. Key words were dated molecular phylogeny, South America, Australia, disjunction. In most cases the obtained phylogenies were dated, but lacked distributional data of the species, which we obtained from Encyclopedia of Life (http://www.eol.org; last accessed: 15 Jan 2014).

The main criterion to add examples to our database was the presence of a (dated) molecular phylogeny for the corresponding genera. During the assembly of the database, we discovered several instances of undated molecular phylogenies exhibiting Gondwanan disjunctions. In such cases we attempted to contact the relevant authors to obtain the required data as aligned matrices. We received three positive replies to our enquiries for aligned data sets; and obtained aligned matrices of the Rhamnaceae (Richardson et al. 2000), the Celastraceae (Simmons et al., 2001) and the Malvaceae (Baum et al., 2004) plant families. 
Unfortunately, we were unable to successfully complete analyses of the Malvaceae and Celastraceae due to a lack of fossil evidence. See Supporting information for the dating of the Rhamnaceae.

Genera in the resulting database were further separated into climatic preference. The online data were also used to establish the ecological preference of the taxa by presuming biome conservatism (Sanmartín et al., 2007), and were classified as either tropical (including sub-tropical and tropical montane environments), temperate (including Mediterranean-like environments) or ambiguous (a broad environmental preference). The disjunction date estimates for the amphi-Pacific taxa were then interpreted with reference to the tectonic reconstruction (Fig. 2).

The data obtained from the literature research were compiled in a table containing the calculated dates of disjunction, the relevant publication and the climatic preference of the genera. Because not all publications make use of the same methods, some disjunction dates may have a confidence interval, if significant for their nodes, while others may not. The error bars from the literature were plotted alongside the age of the disjunctions in a graph (Fig. 3), and omitted when no information was available. By doing this, it was possible to scale the graph according to time of disjunction as well as to the three climatic preferences. The calculations for the mean age of the disjunctions per phylum (Table 2) were based on the centroids of the ages of the disjunctions as given for the taxa in the literature. These mean values are thus very rough indications for the disjunctions in all phyla, because the variation in the dates was not taken in account.

\section{Results}

All instances of amphi-Pacific distributions that we could trace are listed in Table 1 and are briefly discussed in the Table S1 (Supporting information). We searched literature 
databases for molecular phylogenies where we suspected amphi-Pacific disjunctions would be present. Multiple disjunctions were often discovered within a phylogeny of genera or across taxa, in such cases every statistically relevant disjunction was added to the database and plotted in time. Table 1 shows the ages of Australian, South American and New Zealand clades, and it also shows the ecological type assigned to each taxon.

In Fig. 3 we visualized the results from Table 1 in graphical form. The data are divided into three climatic conditions: (1) tropical-sub-tropical (red); (2) temperate (blue), and: (3) mixed (purple). We have also indicated instances of unknown climatic preferences or when the climate showed a wide range with white dots.

To analyze our data further, mean ages of disjunctions were calculated considering taxa and climatic preferences (Table 2). The data were subdivided into the corresponding phyla and climatic occurrences, and undated disjunctions were omitted from the calculations. From the mean calculations we noted a trend in which tropical species exhibit earlier disjunctions than temperate taxa (Table 2). Of the 16 dated plant taxa that were analyzed, 13 were confidently estimated to be of vicariant origin. The mean age of disjunction for all plant species lies at 48.5 Ma (Early Eocene). When further subdivided the tropical plants have a mean age of c. 55.4 Ma and the temperate ones c. $36.9 \mathrm{Ma}$.

The vertebrates show a mean age of disjunction of c. $50.5 \mathrm{Ma}$; interestingly, very close to that of the plant disjunctions. As the available literature on the Marsupialia and birds provided no climate preferences within the genera, it was impossible to assign climatic preferences to the species at each disjunction.

The mean disjunction age for the invertebrates was calculated at $51.5 \mathrm{Ma}$; an age also very similar to the age calculated for plants and vertebrates. Further subdivision of the invertebrates according to their respective climatic preferences, results in a mean age of 
disjunction for tropical/sub-tropical lineages at 66.7 Ma, and 36.3 Ma for Mediterranean and temperate disjunctions. This is a similar trend to what is observed in the plant records.

We ignore the fungi, for only one analyzed (and undated) disjunction was found, and the research pointed to a LDD event in this case (Foighil et al., 1999).

Within the Mollusca we acquired only one dated phylogeny (56.5 Ma) of a sub-tropical species, which we assigned to vicariance. One other undated phylogeny was found, however, it pointed to an LDD event (Foighil et al., 1999).

The Bryophytes (only one study, Heinrichs et al., 2006) show two tropical species that diverged at $c .51 \mathrm{Ma}$. The remaining four temperate species were calculated to have a mean disjunction at c. $32.3 \mathrm{Ma}$, similar to the previously calculated disjunctions for vascular plants and invertebrates.

The mean time for every dated disjunction in Table 1 was calculated to be $48 \mathrm{Ma}$. We subdivided the entire data set into tropical and temperate disjunctions, the mean disjunction of every tropical lineage lies at c. $57 \mathrm{Ma}$, and the temperate lineages have a mean of $35.3 \mathrm{Ma}$, in line with our expectations.

\section{Discussion and Conclusions}

Our data represent the (dated) phylogenies that show the amphi-Pacific disjunction. The data clearly indicate a majority of lineage splits between South America and Australasia occurred when South America was connected to Australia via the Antarctic land bridge (Phase I, >45 Ma; Fig. 3). During Phase I all three dispersal mechanisms could have been present, but LDD is somewhat less likely, because of the absence of strong circumpolar winds and sea currents. We would expect most vicariance events to have occured during/at the end of Phase I. Vicariance and especially pseudo-vicariance (dispersal over short distances) are expected to occur between Australia and Antarctica during Phase II (45-30 Ma), when Australia and 
Antarctica finally detached. This is especially the case when island chains potentially existed between the two continents (e.g. along the South Tasman Rise; 3). We would expect an increasing shift towards LDD events between Australia and Antarctica at the end of this phase. Vicariance may have remained the main speciation mechanism between South America and Antarctica during Phase II.

After Australia and Antarctica's final separation at ca. $45 \mathrm{Ma}$ (White et al., 2013), South America and Antarctica remained connected, for another c. 15 Myr (Phase II; Fig. 2). Considering the climate at the time, Antarctica may well have acted as a refuge for ostensibly Gondwanan species, which would then exhibit a more recent disjunction, after they crossed back into South America.

In Phase III, when both Australia and South America were detached from Antarctica, LDD was the only dispersal mechanism. We are confident of the separation from Antarctica at these times, particularly with recent independent evidence indicating the onset of the Antarctic Circumpolar Current from c. 30 Ma (Scher et al., 2015).

Following our current understanding of the sequence of events leading to the break-up of Gondwanan tropical clades exhibit, on average, earlier disjunctions than non-tropical ones, because the modern day, northern tropical regions of South America and Australia have been at lower latitudes (closer to the equator) for a longer period of time relative to the southern parts of each continent.

Apparently, most of the tropical taxa have disjunctions before, or at $50 \mathrm{Ma}$, and most temperate taxa have disjunctions dated at or after $40 \mathrm{Ma}$. A notable exception is the early, temperate disjunction occurring within the Littorinidae at $56.5 \pm 16.5 \mathrm{Ma}$ (Williams et al., 2003), though these species inhabit temperate southern oceans. It is possible that the stem group, that has been dated to the Cretaceous, were tolerant of higher temperatures as discussed in Williams et al. (2003), therefore it is difficult to confidently assign a preferred 
climate. However, these species are currently only distributed in temperate southern seas (Williams et al., 2003), and the reason we assigned a temperate climate to the Austrolittorina. The results of Winkworth et al. (2015) that show disjunctions at or after $40 \mathrm{Ma}$ for temperate taxa agree with our results. Winkworth et al. (2015) especially considered temperate and cold climate taxa. The latter had a main dispersal phase between $14 \mathrm{Ma}$ and $4 \mathrm{Ma}$. When these results (Winkworth et al., 2015) are considered together with our own, a pattern of progression appears of taxa diversifying sequentially from Tropical to Temperate to Cool to Cold through time. We also observe a trend where temperate species start diversifying after the appearance of Antarctic ice sheets, at c. $35 \mathrm{Ma}$ (Fig. 3).

The disjunction of the Australian, tropical-montane Arecaceae Oraniopsis appendiculata with the South American genus Ceroxylon at 32 Ma (Berry et al., 2004) is unexpected, as this conflicts with the observed trend in tropical species (these lineages tend to split earlier). Similarly, within the Haloragaceae, the tropical, Australian Myriophyllum pedunculatum and the South American M. aquaticum exhibit a disjunction at an estimated $21 \pm 14 \mathrm{Ma}$ (Les et al., 2003); 21 Ma post-dates the final break up of the Antarctic-South American land bridge by approximately $9 \mathrm{Myr}$. With a calculated confidence interval of $\pm 14 \mathrm{Myr}$ it is impossible to rule out that this disjunction occurred before the final break-up of the Antarctic-South American land bridge. Considering the relatively recent disjunction, and it being a tropical species we do not favor a vicariant origin.

In the course of the literature study we came across some interesting cases of (possible) vicariance events in birds and fish, which show that one cannot always deduce the dispersal/speciation mechanism from the animal's behavior. A vicariant pattern was found in passerine birds (Ericson et al., 2002). While birds in general arguably possess the best LDD mechanism - flight, it is possible that breeding habits, which are often area specific, lead to vicariance or pseudo-vicariance as the breeding grounds split up. In terms of fish, some 
Galaxiid species exhibit amphidromous reproduction behavior, spending their juvenile phase in salt water, while adult fish are always found in fresh water (Burridge et al., 2012). It is possible that some fish dispersed as juveniles across the Tasman Sea/Southern Ocean, or possibly, through the south Equatorial current (a warm water current, the southern arm of which runs from Australia to New Zealand and then to South America). However, in this case LDD between South America and Australia is improbable for these Galaxiid species as the salt water distance between South America and Australia likely would have been too far to cross during the timespan of the fish's juvenile phase.

The ongoing debate between proponents of LDD and proponents of continental vicariance often results in polarized, dogmatic views on either theory. We propose a view in which vicariance and the dispersal-founder effect lead to similar biogeographic patterns throughout amphi-Pacific genera. Thereby, we do not exclude the possibility of LDD events as some evidence of these events is irrevocable, however, some biogeographers fail to recognize the geological sequence of events, preferring LDD explanations even when more parsimonious, vicariant or pseudo-vicariant explanations are possible. The evidence from our literature study, combined with a well established geological history point to a possibly overwhelmingly (pseudo-)vicariant scenario within the Gondwanan genera we reviewed.

Plate reconstructions of Gondwana indicate the last terrestrial connection between Antarctica and South America was at c. $30 \mathrm{Ma}$ (Fig. 2). The last connection between Australia and Antarctica (via the South Tasman Rise) was severed at c. $45 \mathrm{Ma}$ (Fig. 2), which is much more recent than many previous authors assumed when discussing the biogeography of their phylogenetic results. Therefore, all of the examples that we collected (Table 1) show a strong signal that that the connection between South America and Australia via Antarctica provided a dispersal pathway and vicariance moment after break up, and this explains the majority of southern amphi-Pacific distributions. 
Tropical taxa exhibited earlier divergence moments than temperate taxa. This pattern follows the break-up sequence of Gondwanan continents, where more northerly regions experienced tropical conditions first, or experienced tropical conditions where more southerly regions did not. Of the 44 reviewed Gondwanan disjunctions, 2 disjunctions were inconclusive, 12 genera showed disjunctions that were younger than the last terrestrial connections between Australia and South America (indicating these originated due to LDD), and 28 genera were confidently dated prior to the final separation of Gondwana.

\section{Acknowledgements}

We are grateful for the helpful cooperation we received from J. E. Richardson, D. A. Baum and M. P. Simmons, who were willing to share their data with us. We would also like to thank Graeme Eagles and three anonymous reviewers for critically evaluating this and earlier versions of our manuscript. Additionally, we kindly acknowledge the support from the Naturalis Biodiversity Center, without which this project would not be possible and C. Mennes for kindly sharing the Corsiaceae phylogeny. L.W. thanks the industrial sponsors of the Southeast Asia Research Group for their financial support as well as The Rothwell Group for providing a license for PaleoGIS plate tectonic reconstruction software.

\section{Author Contributions}

C.v.d.E and P.v.W. conceived the ideas, C.v.d.E. collected most materials and contributed molecular data; L.W. contributed the geological interpretations and plate reconstructions, all analyzed the data and C.v.d.E. wrote the majority of the manuscript, followed by L.W.; all authors contributed significantly to improving the manuscript. 


\section{References}

Barker NP, Weston PH, Rutschmann F, Sauquet H (2007) Molecular dating of the 'Gondwanan' plant family Proteaceae is only partially congruent with the timing of the break-up of Gondwana. J Biogeogr 34: 2012-2027.

Baum DA, DeWitt Smith S, Yen A, Alverson WS, Nyffeler R, Whitlock BA, Oldham RL (2004) Phylogenetic relationships of Malvatheca (Bombacoideae and Malvoideae; Malvaceae sensu lato) as inferred from plastid DNA sequences. Am J Bot 91: 18631871.

Beck RM (2008) A dated phylogeny of marsupials using a molecular supermatrix and multiple fossil constraints. J Mammal 89: 175-189.

Berry PE, Hahn WJ, Sytsma KJ, Hall JC, Mast A (2004) Phylogenetic relationships and biogeography of Fuchsia (Onagraceae) based on noncoding nuclear and chloroplast DNA data. Am J Bot 91: 601-614.

Boger SD (2011) Antarctica - Before and after Gondwana. Gondwana Res 19: 335-371.

Brammer CA, von Dohlen CD (2007) Evolutionary history of Stratiomyidae (Insecta:

Diptera): The molecular phylogeny of a diverse family of flies. Mol Phylogenet Evol 43: $660-673$.

Burridge CP, McDowall RM, Craw D, Wilson MV, Waters JM (2012) Marine dispersal as a pre-requisite for Gondwanan vicariance among elements of the galaxiid fish fauna. $\mathbf{J}$ Biogeogr 39: 306-321.

Cook LG, Crisp MD (2005) Not so ancient: the extant crown group of Nothofagus represents a post-Gondwanan radiation. Proc Roy Soc London, Ser B, Biol Sci 272: 2535-2544.

Crayn DM, Rossetto M, Maynard DJ (2006) Molecular phylogeny and dating reveals an Oligo-Miocene radiation of dry-adapted shrubs (former Tremandraceae) from rainforest tree progenitors (Elaeocarpaceae) in Australia. Am J Bot 93: 1328-1342. 
Crisp MD, Arroyo MTK, Cook LG, Gandolfo MA, Jordan GJ, McGlone MS, Weston PH, Westoby M, Wilf P, Linder HP (2009) Phylogenetic biome conservatism on a global scale. Nature 458 (9 Apr.): 754-756.

Eagles G, Jokat W (2014) Tectonic reconstructions for paleobathymetry in Drake Passage. Tectonophysics 611: 28-50.

Ericson PG, Christidis L, Cooper A, Irestedt M, Jackson J, Johansson US, Norman JA (2002) A Gondwanan origin of passerine birds supported by DNA sequences of the endemic New Zealand wrens. Proc Biol Sci 269: 235-241.

Exon N, Kennett JP, Malone MJ (2001) Leg 189 Summary. Proc Ocean Drill Program Init Repts: 189, 1-98.

Foighil DÓ, Marshall BA, Hilbish TJ, Pino MA (1999) Trans-Pacific range extension by rafting is inferred for the flat oyster Ostrea chilensis. Biol Bull 196: 122-126.

Frey W, Stech M, Meissner K (1999) Chloroplast DNA-relationship in palaeoaustral Lopidium concinnum (Hypopterygiaceae, Musci). An example of stenoevolution in mosses. Studies in austral temperate rain forest bryophytes 2. Plant Syst Evol 218: 6775.

Gaina C, Müller RD, Brown B, Ishihara T, Ivanov S (2007) Breakup and early seafloor spreading between India and Antarctica. Geophys J Int 170: 151-169.

Gaina C, Müller DR, Royer, J-Y, Stock J, Hardebeck J, Symonds P (1998) The tectonic history of the Tasman Sea: a puzzle with 13 pieces. J Geophys Res 103: 12413-12433.

Giribet G, Edgecombe GD (2006) The importance of looking at small-scale patterns when inferring Gondwanan biogeography: a case study of the centipede Paralamyctes (Chilopoda, Lithobiomorpha, Henicopidae). Biol J Linn Soc Lond 89: 65-78.

Heinrichs J, Linder M, Groth H, Hentschel J, Feldberg K, Renker C, Engel JJ, von Konrat M, Long DG, Schneider H (2006) Goodbye or welcome Gondwana?-insights into the 
phylogenetic biogeography of the leafy liverwort Plagiochila with a description of Proskauera, gen. nov. (Plagiochilaceae, Jungermanniales). Plant Syst Evol 258: 227-250.

Hill ED (2009) Salticidae of the Antarctic land bridge. Peckhamia 76: 1-14.

König M, Jokat W (2006) The Mesozoic breakup of the Weddell Sea. J Geophys Res Solid Earth 111: B12102, doi: 10.1029/2005JB004035

Korall P, Pryer KM (2014) Global biogeography of scaly tree ferns (Cyatheaceae): evidence for Gondwanan vicariance and limited transoceanic dispersal. J Biogeogr 41: 402-413.

Krosch M, Cranston PS (2013) Not drowning, (hand) waving? Molecular phylogenetics, biogeography and evolutionary tempo of the 'Gondwanan' midge Stictocladius Edwards (Diptera: Chironomidae). Mol Phylogenet Evol 68: 595-603.

Krosch MN, Baker AM, Mather PB, Cranston PS (2011) Systematics and biogeography of the Gondwanan Orthocladiinae (Diptera: Chironomidae). Mol Phylogenet Evol 59: 458468.

Lawver LA, Gahagan LM (1994) Constraints on timing of extension in the Ross Sea region. Terra Antarctica 1: 545-552.

Lawver LA, Gahagan LM (2003) Evolution of Cenozoic seaways in the circum-Antarctic region. Palaeogeogr Palaeoclimatol Palaeoecol 198: 11-37.

Les DH, Crawford DJ, Kimball RT, Moody ML, Landolt E (2003) Biogeography of discontinuously distributed hydrophytes: a molecular appraisal of intercontinental disjunctions. Int J Plant Sci 164: 917-932.

McLoughlin S (2001) The breakup history of Gondwana and its impact on pre-Cenozoic floristic provincialism. Aust J Bot 49: 271-300.

Moncalvo JM, Buchanan PK (2008) Molecular evidence for long distance dispersal across the Southern Hemisphere in the Ganoderma applanatum-australe species complex (Basidiomycota). Mycol Res 112: 425-436. 
Nylinder S, Swenson U, Persson C, Janssens SB, Oxelman B (2012) A dated species-tree approach to the trans-Pacific disjunction of the genus Jovellana (Calceolariaceae, Lamiales). Taxon 61: 381-391.

Pérez-Díaz L, Eagles G (2014) Constraining South Atlantic growth with seafloor spreading data. Tectonics 33: 1848-1873.

Reeves C (2014) The position of Madagascar within Gondwana and its movements during Gondwana dispersal. J Afr Earth Sci 94: 45-57.

Richardson JE, Fay MF, Cronk QC, Bowman D, Chase M (2000) A phylogenetic analysis of Rhamnaceae using rbcL and trnL-F plastid DNA sequences. Am J Bot 87: 1309-1324. Royer JY, Rollet N (1997) Plate- tectonic setting of the Tasmanian region. Aust J Earth Sci 44: 543-560.Scotese CR, Boucot AJ, McKerrow WS. 1999. Gondwanan Palaeogeography and palaeoclimatology. J African Earth Sci 28: 99-114.

Sanmartín I, Ronquist F (2004) Southern Hemisphere biogeography inferred by event-based models: plant versus animal patterns. Syst Biol 53: 216-243.

Sanmartín I, Wanntorp L, Winkworth RC (2007) West Wind Drift revisited: testing for directional dispersal in the Southern Hemisphere using event-based tree fitting. $\mathbf{J}$ Biogeogr 34: 398-416.

Sayers J, Symonds P, Direen N, Bernardel G (2001) Nature of the continent-ocean transition on the non-volcanic rifted margin of the central Great Australian Bight. Geol Soc Spec Publ 187: 51-76.

Scher HD, Whittaker JM, Williams SE, Latimer JC, Kordesch WEC, Delaney ML (2015) Onset of Antarctic Circumpolar Current 30 million years ago as Tasmanian Gateway aligned with westerlies. Nature 523: 580-583.

Sequeira AS, Farrell BD (2001) Evolutionary origins of Gondwanan interactions: How old are Araucaria beetle herbivores? Biol J Linn Soc Lond 74: 459-474. 
Simmons MP, Savolainen V, Clevinger CC, Archer RH, Davis JI (2001) Phylogeny of the Celastraceae inferred from 26S nuclear ribosomal DNA, phytochrome B, rbcL, atpB, and morphology. Mol Phylogenet Evol 19: 353-366.

Tikku AA, Direen NG (2008) Comment on "Major Australian-Antarctic Plate Reorganization at Hawaiian Emperor Bend Time”. Science 321: 490c.

Torsvik TH, Müller RD, Van Der Voo R, Steinberger B, Gaina C (2008) Global plate motion frames: Toward a unified model. Rev Geophys 46: 1-44.

Trénel P, Gustafsson MHG, Baker WJ, Asmussen-Lange CB, Dransfield J, Borchsenius F (2007) Mid-Tertiary dispersal, not Gondwanan vicariance explains distribution patterns in the wax palm subfamily (Ceroxyloideae: Arecaceae). Mol Phylogenet Evol 45: 272288.

Van Steenis CGGJ (1962) The land-bridge theory in botany, with particular reference to tropical plants. Blumea 11: 235-542.

Veevers JJ (2012) Reconstructions before rifting and drifting reveal the geological connections between Antarctica and its conjugates in Gondwanaland. Earth-Sci Rev 111: 249-318.

Wegener A (1929) Die Entstehung der Kontinente und Ozeane Braunschweig : Friedr. Vieweg \& Sohn Akt. Ges.

White LT, Lister GS (2012) The collision of India with Asia. J Geodyn 56-57: 7-17.

White LT, Gibson GM, Lister GS (2013) A reassessment of paleogeographic reconstructions of eastern Gondwana: Bringing geology back into the equation Gondwana Res 24: 984 998.

Williams ST, Reid DG, Littlewood DTJ (2003) A molecular phylogeny of the Littorininae (Gastropoda: Littorinidae): unequal evolutionary rates, morphological parallelism, and biogeography of the Southern Ocean. Mol Phylogenet Evol 28: 60-86. 
Winkworth RC, Hennion F, Prinzing A, Wagstaff SJ (2015) Explaining the disjunct distributions of austral plants: the roles of Antarctic and direct dispersal routes. J Biogeogr 42: 1197-1209.

Zachos J, Pagani M, Sloan L, Thomas E, Billups K (2001) Trends, rhythms, and aberrations in global climate 65 Ma to present. Science 292: 686-693. 
Table 1: Overview of literature containing molecularly dated species disjunctions, including species' climatic preference, and hypothesized divergence scenario. *= Ancestral Area reconstruction indicates a Plant Southern Pattern (PSP) and, therefore, a vicariant scenario (3). AU = Australia, NZ = New Zealand, SA = South America; vs = versus. Phase I: older than 45 Ma, II: 30-45 MA, III: younger than 30 Ma; assignment based on centroid in Fig. 3.

\begin{tabular}{|c|c|c|c|c|c|c|c|}
\hline Higher Taxon: Lower Taxa & Reference & AU clade in $\mathrm{Ma}$ & SA clade in Ma & NZ clade in Ma & Phase & Vicariance/I & Climate type \\
\hline Passerine birds: Oscines (AU) vs Suboscines (SA) \&Wrens (NZ) & Ericson et al., 2002 & $<34 \mathrm{Ma}$ & $<40 \mathrm{Ma}$ & $82-85 \mathrm{Ma}$ & II & Vicariance & Temperate-Tropical \\
\hline Marsupials: Order Australidelphia (AU) vs Order Ameridelphia (SA) & Beck, 2008 & $57.9-70.9 \mathrm{Ma}$ & $65.2-86.2 \mathrm{Ma}$ & N/A & I & Vicariance & Temperate-Tropical \\
\hline Galaxiid fish: Genus Lovetia (AU) vs Genus Aplochiton (SA) & Burridge et al., 2012 & $55 \pm 20 \mathrm{Ma}$ & $55 \pm 20 \mathrm{Ma}$ & N/A & I & Vicariance & Tropical-S.Temperat \\
\hline Galaxiid fish: Genus Galaxiella (AU) vs sister group (widespread) & Burridge et al., 2012 & $58 \pm 14 \mathrm{Ma}$ & N/A & N/A & I & \begin{tabular}{l|l} 
Vicariance \\
\end{tabular} & Tropical-S.Temperat \\
\hline Galaxiid fish: Genus Brachygalaxias (SA) vs sister group (widespread, AU) V & Burridge et al., 2012 & N/A & $46 \pm 11 \mathrm{Ma}$ & N/A & I & Vicariance & Tropical-S.Temperat \\
\hline $\begin{array}{l}\text { Galaxiid fish: Galaxias platei (SA) vs Neochanna cleaveri (AU) vs NZ clade } \\
\text { Neochanna }\end{array}$ & Burridge et al., 2012 & $31 \pm 7 \mathrm{Ma}$ & $31 \pm 7 \mathrm{Ma}$ & $31 \pm 7 \mathrm{Ma}$ & II & LDD & Tropical-S.Temperat \\
\hline Oyster: Ostrea chilensis (NZ) vs O. chilensis (SA) & Foighil et al., 1999 & N/A & N/A & N/A & - & LDD & Temperate \\
\hline $\begin{array}{l}\text { Diptera: Chironomidea genus Stictocladius: Split between AU and SA species } \\
\text { "Sofour A and Sofour B" }\end{array}$ & $\begin{array}{l}\text { Krosch and Cranston, } \\
2013\end{array}$ & $37 \pm 13 \mathrm{Ma}$ & $37 \pm 13 \mathrm{Ma}$ & N/A & II & Vicariance/1 & S. Temperate \\
\hline Diptera: Chironomidea: Botryocladius edwards (SA) vs B. freemanni (AU) & Krosch et al., 2011 & c. $31 \mathrm{Ma}$ & c. $31 \mathrm{Ma}$ & N/A & II & LDD & S. Temperate \\
\hline Diptera: Chironomidea: Botryocladius grapeth (AU) vs B. mapuche (SA) & Krosch et al., 2011 & c. $41 \mathrm{Ma}$ & c. $41 \mathrm{Ma}$ & N/A & II & Vicariance & S. Temperate \\
\hline Chilopoda: Paralamyctes & Giribet and Edgecombe, & N/A & N/A & N/A & - & Vicariance// & S. Temperate \\
\hline Basidiomycota: Ganoderma applanatum - G. australe & Moncalvo and Buchanan & N/A & N/A & N/A & - & LDD & Temperate \\
\hline Gastropoda: Littorinidae, Austrolittorina: South American vs Australian species. & Williams et al., 2003 & $56.5 \pm 16.5 \mathrm{Ma}$ & $56.5 \pm 16.5 \mathrm{Ma}$ & N/A & I & Vicariance & Temperate \\
\hline
\end{tabular}




\begin{tabular}{|c|c|c|c|c|c|c|c|}
\hline Cyatheaceae: within genus Sphaeropteris: AU vs SA clade. & Korall and Pryer, 2014 & Origin $>80 \mathrm{Ma}$ & $39.5 \pm 3.5 \mathrm{Ma}$ & N/A & II & Vicariance & Tropical - Sub-tropic \\
\hline Cyatheaceae: within genus Cyathea: AU vs SA clade & Korall and Pryer, 2014 & $68 \pm 14 \mathrm{Ma}$ & $68 \pm 14 \mathrm{Ma}$ & $\mathrm{N} / \mathrm{A}$ & I & Vicariance & Tropical - Sub-tropic \\
\hline Cyatheaceae: within genus Alsophila: AU vs SA clade & Korall and Pryer, 2014 & $51 \pm 11 \mathrm{Ma}$ & $51 \pm 11 \mathrm{Ma}$ & N/A & I & Vicariance & Tropical - Sub-tropic \\
\hline Marchantiophyta: Plagiochila gigantea (AU) vs $P$. cf. obcuneata (SA) & Heinrichs et al., 2006 & c. $32 \mathrm{Ma}$ & c. $32 \mathrm{Ma}$ & $\mathrm{N} / \mathrm{A}$ & II & LDD & S. Temperate \\
\hline Marchantiophyta: Plagiochila banksiana (AU) vs $P$. obovata (SA) & Heinrichs et al., 2006 & c. $38 \mathrm{Ma}$ & c. $38 \mathrm{Ma}$ & N/A & II & Vicariance & Temperate \\
\hline Marchantiophyta: Plagiochila retrospectans (AU) vs (SA) Sister clade & Heinrichs et al., 2006 & c. $50 \mathrm{Ma}$ & c. $50 \mathrm{Ma}$ & N/A & I & Vicariance & Tropical \\
\hline Marchantiophyta: Plagiochila deltoidea (AU) vs $P$. acanthocaulis (SA) & Heinrichs et al., 2006 & c. $31 \mathrm{Ma}$ & c. $31 \mathrm{Ma}$ & N/A & II & LDD & Temperate \\
\hline Marchantiophyta: Plagiochila crozetensis (Ant) vs $P$. dura (SA) & Heinrichs et al., 2006 & $\mathrm{~N} / \mathrm{A}$ & c. $28 \mathrm{Ma}$ & $\mathrm{N} / \mathrm{A}$ & III & LDD & Temperate \\
\hline Marchantiophyta: Plagiochila fasciculata \& P. circinalis (AU) vs (SA) Sister clade & Heinrichs et al., 2006 & c. $52 \mathrm{Ma}$ & c. $52 \mathrm{Ma}$ & N/A & I & Vicariance & Tropical \\
\hline Nothofagaceae: within subgenus Brassospora (SA) vs AU clade & Cook and Crisp., 2005 & c. $45 \mathrm{Ma}$ & c. $45 \mathrm{Ma}$ & N/A & I & Vicariance & Temperate \\
\hline Nothofagaceae: within subgenus Fuscospora (SA) vs AU clade & Cook and Crisp., 2005 & c. $45 \mathrm{Ma}$ & c. $45 \mathrm{Ma}$ & $\mathrm{N} / \mathrm{A}$ & I & Vicariance & S. Temperate \\
\hline Nothofagaceae: within subgenus Lophozonia (SA) vs AU clade & Cook and Crisp., 2005 & c. $30 \mathrm{Ma}$ & c. $30 \mathrm{Ma}$ & N/A & II & LDD & S. Temperate \\
\hline Elaeocarpaceae: Aristotelia chilensis (SA) vs Aristotelia (AU/TA/NZ) clade & Crayn et al., 2006 & $25.5 \pm 1.5 \mathrm{Ma}$ & $25.5 \pm 1.5 \mathrm{Ma}$ & $25.5 \pm 1.5 \mathrm{Ma}$ & III & LDD & Temperate \\
\hline Elaeocarpaceae: Genus Peripentadenia (AU) vs Genus Crinodendron (SA) & Crayn et al., 2006 & $82 \pm 9 \mathrm{Ma}$ & $82 \pm 9 \mathrm{Ma}$ & N/A & $\mathrm{I}$ & Vicariance & Tropical \\
\hline Proteaceae: Genus Telopea (Au/Ta) vs Genus Embothrium (SA) & Barker et al., 2007 & $45.8 \pm 7 \mathrm{Ma}$ & $45.8 \pm 7 \mathrm{Ma}$ & N/A & I & Vicariance & S. Temperate \\
\hline Proteaceae: Genus Cardwellia (AU) vs Genus Gevuina (SA) & Barker et al., 2007 & $51.4 \pm 10 \mathrm{Ma}$ & $51.4 \pm 10 \mathrm{Ma}$ & N/A & I & Vicariance & Tropical \\
\hline Onagraceae: Genus Fuchsia (SA) vs Skinnera (AU) clade. & Berry et al., 2004 & c. $30 \mathrm{Ma}$ & c. $30 \mathrm{Ma}$ & $\mathrm{N} / \mathrm{A}$ & II & LDD & S. Temperate \\
\hline Arecaceae: Oraniopsis appendiculata (AU) vs Genus Ceroxylon (SA) & Trénel et al., 2007 & c. $32 \mathrm{Ma}$ & c. $32 \mathrm{Ma}$ & N/A & II & LDD & Tropical montane \\
\hline Podostemaceae: Tristicha (AU) vs Mourera (SA) & Les et al., 2003 & c. $104 \mathrm{Ma}$ & c. $104 \mathrm{Ma}$ & $\mathrm{N} / \mathrm{A}$ & I & Vicariance & Sub-tropical-Tropica \\
\hline Juncaginaceae: Cycnogeton (AU) vs Tetroncium (SA) & Les et al., 2003 & c. $52 \mathrm{Ma}$ & c. $52 \mathrm{Ma}$ & N/A & I & Vicariance & Sub-tropical-Tropica \\
\hline Haloragaceae: Myriophyllum pedunculatum (AU) vs M. aquaticum (SA) & Les et al., 2003 & $21 \pm 14.4 \mathrm{Ma}$ & $21 \pm 14.4 \mathrm{Ma}$ & N/A & III & LDD & Sub-tropical-Tropica \\
\hline Calceolariaceae: Jovellana sinclairii \& J. repens $(\mathrm{NZ})$ vs J. violacea \& J. punctata $(\mathrm{S}$ & Nylinder et al., 2012 & N/A & c. $4 \mathrm{Ma}$ & c. $4 \mathrm{Ma}$ & III & LDD & ? \\
\hline Hypopterygiaceae: Lopidium concinnum (AU) vs L. concinnum (SA) & Frey et al., 1999 & N/A & N/A & N/A & - & Vicariance & Temperate \\
\hline
\end{tabular}




\begin{tabular}{|c|c|c|c|c|c|c|c|}
\hline Diptera: Family Stratiomyidae, Lagenosoma (AU) vs Auloceromyia (SA) & Brammer and von Dohles & c. $42 \mathrm{Ma}$ & N/A & N/A & II & Vicariance & Tropical \\
\hline Diptera: Stratiomydae, Lecomyia (AU) vs Cyanauges (SA) & Brammer and von Dohles & c. $80 \mathrm{Ma}$ & N/A & N/A & I & Vicariance & Sub-tropical \\
\hline Coleoptera: Auracaria Hylurdrectronus (AU) clade vs Hylurdrectronus (SA) clade & Sequeira and Farrell, 200 & $78 \pm 13 \mathrm{Ma}$ & N/A & N/A & I & Vicariance & Tropical - Sub-tropic \\
\hline Corsiaceae: Arachnitis uniflora (SA) vs Corsia sp. (AU) & C. Mennes, pers. comm. & $53 \pm 23$ & N/A & N/A & I & Vicariance & Tropical \\
\hline
\end{tabular}


Table 2: Total numbers and mean age of disjunctions calculated from Table 1, taking into account climatic preference. Tropical (Tr.) to subtropical (Sub-Tr.) species sorted together, and Southern temperate (S. temp.) and temperate (temp.) species were sorted together. Mean ages for the climate preferences were not calculated for vertebrate examples as their climatic preferences are ambiguous and influenced by factors as migration. Vicariance as determined by authors. *Establishment of New Zealand lineages birds omitted from mean calculation.**Study is not dated.*** Only one dated study applicable for age of disjunction. **** Excluding one ambiguous split.***** Excluding Frey et al., 1999 for mean age calculation.

\begin{tabular}{|l|l|l|l|l|l|l|}
\hline Phyla & Total \# of disjunctions & Vicariance & LDD & Mean age of disjunction. & Tr-Sub-Tr Mean age of disjunction. & S. temp.-temp. Mean age of disjunction. \\
\hline Plants & 16 & 11 & 5 & $48.5 \mathrm{Ma}$ & $55.4 \mathrm{Ma}$ & $36.9 \mathrm{Ma}$ \\
\hline Vertebrates & $8(9)^{*}$ & 8 & 1 & $50.5 \mathrm{Ma}$ & N/A & N/A \\
\hline Invertebrates & $6(7)^{* * * *}$ & 4 & 1 & 51.5 & $66.7 \mathrm{Ma}$ & $36.3 \mathrm{Ma}$ \\
\hline Fungi & 1 & 0 & 1 & N/A** & N/A & N/A \\
\hline Mollusca*** & 2 & 1 & 1 & 56.5 & 56.5 & N/A \\
\hline Bryophytes & $6(7)^{* * * * *}$ & 4 & 3 & 36.8 & $51 \mathrm{Ma}$ & $32.3 \mathrm{Ma}$ \\
\hline Total & $40(42)$ & 28 & 12 & $48 \mathrm{Ma}$ & $57 \mathrm{Ma}$ & $35.3 \mathrm{Ma}$ \\
\hline
\end{tabular}




\section{LEGENDS TO THE FIGURES}

Fig. 1. a: Map showing the present day locations of the coastlines (green polygons) and estimated plate boundaries (blue polygons) for the continents that were once part of Gondwana (e.g. Antarctica, Australia, South America, Africa). The blue polygons (and any overlying coastlines) were restored in the tectonic reconstructions shown in Figure 2. Map projection: Australian-Antarctic Polar Stereographic WGS1984 b: Tectonic reconstruction of the continents and continental fragments shown in (a) showing the configuration of Gondwana 170 million years ago (Ma). Map projection: Australian-Antarctic Polar Stereographic WGS1984.

Fig. 2: Series of plate reconstructions at different periods (a: $45 \mathrm{Ma} \mathrm{b}: 40 \mathrm{Ma}$ c: $35 \mathrm{Ma}$ d: $30 \mathrm{Ma}$ e: $25 \mathrm{Ma}$ f: $20 \mathrm{Ma}$ ) showing the final stages of the break-up of Gondwana with the separation of Australia and Antarctica as well as South America and Antarctica. The purple (or dark grey) polygon shows the interpreted connection between South America and Antarctica. The black polygon shows the location of the South Tasman Rise which represents the final connection between Australia and Antarctica. The South Tasman Rise was submerged beneath approximately 1000m of water between 50 to 32 Ma (Lawver \& Gahagan, 1994; Exon et al., 2001), however, throughflow and much deeper waters did not develop until 35-30 Ma (Exon et al., 2001; Scher et al., 2015). The plate reconstructions were largely generated from previously published reconstruction data (Lawver \& Gahagan, 1994; Gaina et al., 1998; Lawver and Gahagan, 2003; König and Jokat, 2006; White and Lister, 2012; White et al., 2013; Eagles and Jokat, 2014; Pérez-Diaz and Eagles, 2014) and were rotated relative to a mantle reference frame 
(Torsvik et al., 2008). Please note that these do not take information on paleoclimate or paleobathymetry into account. Map projection: Australian-Antarctic Polar Stereographic WGS1984.

Fig. 3: Clade disjunctions plotted in time. Horizontal black bars indicate the range of error calculated for each disjunction separately. Colored dots indicate the climatic preferences of the species: Blue: Temperate; Purple: Mediterranean/Tropical montane; Red: Tropical. Vertical grey bars indicate the timing of the separation of the continental plates: SW-AU:Ant = Southwestern Australia from Antarctica; NZ:Ant = part of future New Zealand from Antarctica; SE-AU:Ant = Southeastern Australia from Antarctica; SA:Ant = South America from Antarctica. The red line indicates global climate trends (vertically extended to be more visible), black horizontal bar indicates presence of Antarctic ice sheets throughout the Neogene, both based on Zachos et al. (2001). 

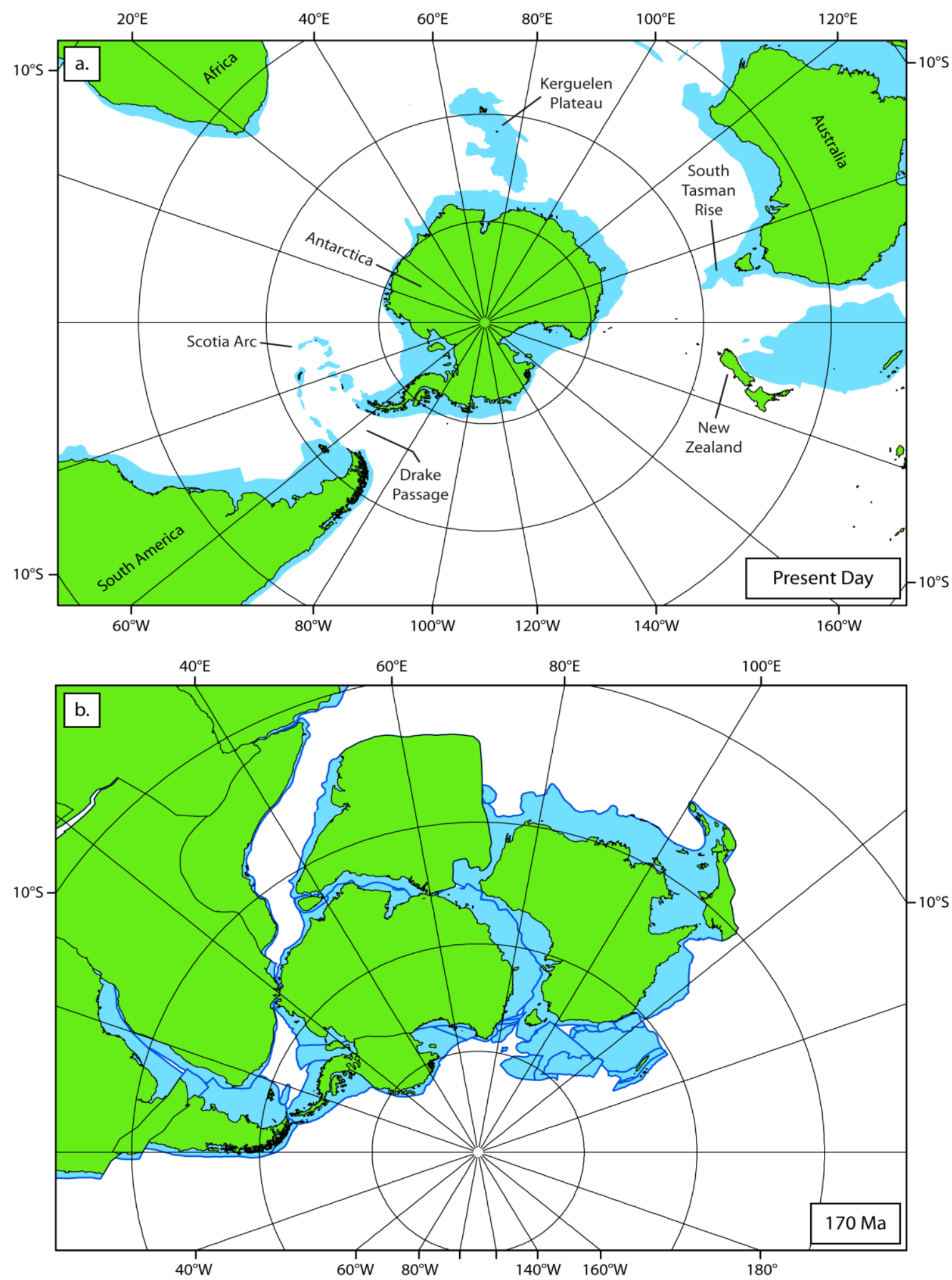

Figure 1 

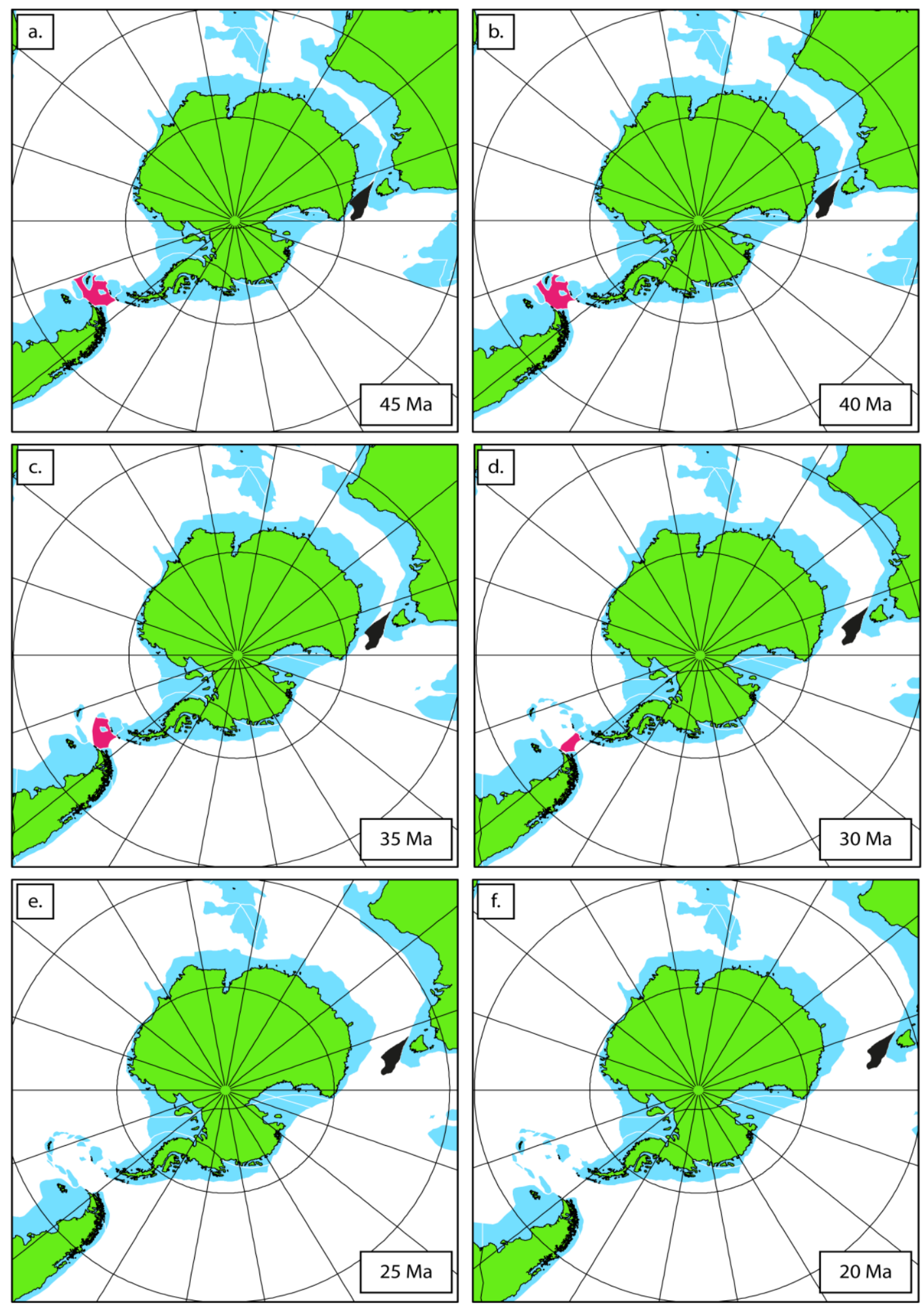

Figure 2 


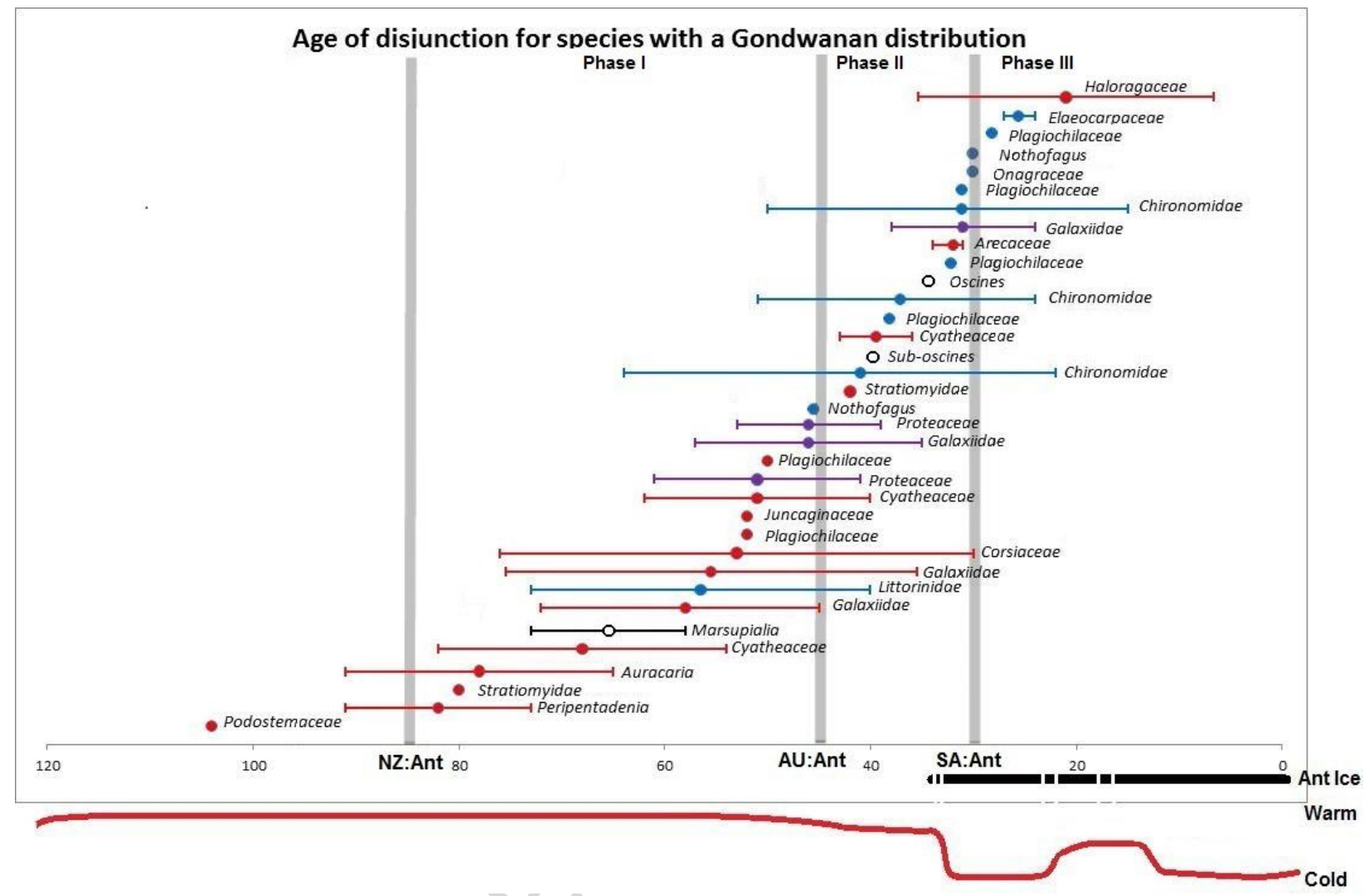

Figure 3 
Research Highlights

The existence and break-up of the Antarctic land bridge as indicated by both amphi-Pacific distributions and tectonics

- South America, Australia and Antarctica formed a union till $45 \mathrm{Ma}$

- Many related taxa show a disjunct distribution between South America and Australia

- The disjuctions are usually theresult of dispersal/vicariance via Antarctica 